\title{
DNA extraction from bronchial aspirates for molecular cytology: Which method to take?
}

\author{
Hans Jürgen Grote ${ }^{\mathrm{a}, *}$, Viola Schmiemann ${ }^{\mathrm{a}}$, Mario Sarbia ${ }^{\mathrm{b}}$ and Alfred Böcking ${ }^{\mathrm{a}}$ \\ ${ }^{a}$ Institute of Cytopathology, Heinrich-Heine-University, Moorenstrasse 5, D-40225 Düsseldorf, Germany \\ ${ }^{\mathrm{b}}$ Institute of Pathology, Heinrich-Heine-University, Moorenstrasse 5, D-40225 Düsseldorf, Germany
}

Received October 2002

Accepted November 2002

\begin{abstract}
Objective: To date, there are only few systematic reports on the quality of DNA extracted from routine diagnostic cytologic specimens. It was the aim of the present study to evaluate the ability of 50\% ethanol $/ 2 \%$ carbowax (Saccomanno fixative) to preserve bronchial secretions with high quality genomic DNA as well as to compare different DNA extraction methods.

Methods: DNA was extracted from 45 bronchial aspirates by four different extraction protocols. Beside DNA yield, DNA quality with regard to purity, integrity, and PCR success rate were investigated.

Results: No fragmentation of sample DNA due to the fixative was detected. It was preserved as high molecular weight DNA. DNA yield, purity, and integrity were dependent on the DNA extraction method to some extend. Irrespective of the DNA extraction method the PCR success rate for amplification of $\beta$-globin gene fragments (268, 536, and 989 bp) was $100 \%$.

Conclusions: A fixative containing $50 \%$ ethanol/2\% carbowax preserves high quality DNA which is well suited for PCRbased assays regardless of the extraction protocol used. The selection of the DNA extraction protocol has to be adjusted to the circumstances of application.
\end{abstract}

Keywords: Molecular cytology, fixative, PCR, bronchi, DNA extraction

\section{Introduction}

The application of molecular biological methods to bronchial aspirates for the diagnostic detection and the investigation of cancer cells is a challenge. Bronchial aspirates contain only a low total amount of DNA as compared with tumor tissue obtained by surgery. In addition, usually only a small portion of total genomic DNA actually represents tumor cell DNA. Thus, obtaining high quality genomic DNA is critical for molecular cytologic studies on bronchial aspirates. It is well known from studies using tissue specimens that the quality of genomic DNA is mainly influenced by the fixative and the method of DNA extraction applied $[2,3]$. However, regarding routine diagnostic cytologic specimens there are only few systematic reports on this topic $[1,5,9]$.

\footnotetext{
${ }^{*}$ Corresponding author: Dr. Hans Jürgen Grote, Institute of $\mathrm{Cy}$ topathology, Heinrich-Heine-University, Moorenstrasse 5, D-40225 Düsseldorf, Germany. Tel.: +49 21181 18837; Fax: +49 21181 18402; E-mail: grote@med.uni-duesseldorf.de.
}

This study investigates the ability of Saccomanno fixative (50\% ethanol/2\% polyethylene glycol [carbowax]) to preserve high quality genomic DNA since this fixative is often used in routine diagnostic cytopathology of the respiratory tract. In addition, the study compares phenol-chloroform DNA extraction to the following alternative methods: (a) NucleoSpin Tissue (Macherey-Nagel, Düren, Germany); (b) Puregene DNA Isolation Kit (Gentra Systems, Minneapolis, MN); (c) QIAamp DNA Mini Kit (Qiagen, Hilden, Germany).

\section{Material and methods}

The present study was carried out on 45 consecutive bronchial aspirates submitted over a two-month period to the Institute of Cytopathology for routine diagnostic purposes. We selected only cases with mild, moderate, or severe bronchitis meeting the following criteria: (a) sufficient residual material remaining after performing routine cytology to prepare four split 
samples; (b) no purulent and clotty material; (c) evaluated as tumor cell negative, as unevenly distributed clusters of hyperdiploid tumor cells might distort the results. Thus, a homogeneous distribution of nuclear DNA in each split sample was ensured. The age of the patients ranged between 32 and 80 (median age, 62). Twenty-one of the individuals were females, and 24 were males.

After bronchoscopy, the specimens were immediately transferred to $50-\mathrm{ml}$ conical tubes containing $20 \mathrm{ml}$ of Saccomanno fixative. On arrival at the laboratory, all samples were primarily processed for routine diagnostic purposes [6]. They were centrifuged at $670 \times g$ for $5 \mathrm{~min}$. A part of the cell pellet was used to prepare conventional smears. They were subsequently stained according to Papanicolaou.

For this study conventional smears were reviewed to examine cellular preservation and bacterial growth as well as to determine the degree of inflammation. A mild, moderate, or severe inflammation was assigned when inflammatory cells (neutrophilic granulocytes, lymphocytes) were scanty, numerous, or predominating respectively.

Residual material was then centrifuged again, the supernatant was decanted, the cell pellet was resuspended in $800 \mu \mathrm{l}$ of Saccomanno fixative and split into four $1.5 \mathrm{ml}$ tubes. The sample DNA was then extracted using the following methods (see Appendix for detailed protocols): (a) phenol-chloroform extraction; (b) NucleoSpin Tissue; (c) Puregene DNA Isolation Kit; (d) QIAamp DNA Mini Kit.

The DNA concentration of each split sample was quantified using UV-spectrophotometry at $260 \mathrm{~nm}$. The DNA yield per aliquot was calculated by multiplying the DNA concentration by the final volume of DNA extract. DNA purity was estimated as ratio of $A_{260} / A_{280}$.

The integrity of genomic DNA was assessed by electrophoresis of DNA extracts on $0.3 \%$ agarose gels.
DNA was visualized by ethidium bromide staining. Each gel was documented with the BioDocAnalyze (Biometra, Göttingen, Germany). The semi-automatic image analysis software of BioDocAnalyze allows measuring the relative migration (RF-value) of sampleDNA and $1 \mathrm{~kb}$ DNA ladder (1 kb DNA Extension Ladder, Invitrogen, USA). Based on the resulting RFvalues it was possible to calculate the size of the DNA fragments.

The adequacy of the DNA extracts for PCR-based assays was assessed by amplifying three different sized fragments of the $\beta$-globin gene $(268,536$, and $989 \mathrm{bp})$ as described by Greer et al. [3]. Amplicons were separated on $1.5 \%$ agarose gels by electrophoresis and visualized by ethidium bromide staining.

For statistical analysis the differences between methods of DNA extraction in DNA concentration, DNA purity, and main DNA fragment size were tested with the Wilcoxon matched-pair signed-rank test for paired observations.

\section{Results}

\subsection{Light microscopy}

Light microscopic review of conventional cytologic smears showed an excellent cellular preservation and no relevant bacterial growth in all cases. The latter was restricted mostly to some oral squamous epithelia. Mild, moderate, and severe bronchitis was present in 10,43 , and 2 cases, respectively.

\subsection{Saccomanno fixative}

Table 1 shows that Saccomanno fixative preserves DNA of bronchial aspirates very well and allows preparation of high molecular-weight DNA. This is

Table 1

DNA yield per split sample of bronchial aspirate, DNA purity, and DNA fragment size related to extraction protocol

\begin{tabular}{|c|c|c|c|}
\hline \multirow[t]{2}{*}{ DNA extraction method } & $\begin{array}{c}\text { DNA yield } \\
{[\mu \mathrm{g}]}\end{array}$ & $\begin{array}{l}\text { DNA purity } \\
{\left[A_{260} / A_{280}\right]}\end{array}$ & $\begin{array}{c}\text { Fragment size } \\
{[\mathrm{kb}]}\end{array}$ \\
\hline & median $(\min ; \max )$ & mean $\pm \mathrm{SD}$ & median $(\min ; \max )$ \\
\hline Phenol-chloroform & $2.76(0.78 ; 55.60)$ & $1.69 \pm 0.16^{*}$ & $>40(>40 ;>40)$ \\
\hline NucleoSpin Tissue & $1.44(0.18 ; 29.28)^{*}$ & $1.70 \pm 0.18^{*}$ & $26(13 ;>40)$ \\
\hline Puregene & $1.53(0.24 ; 30.90)$ & $1.77 \pm 0.16$ & $>40(17 ;>40)$ \\
\hline QIAamp DNA Mini Kit & $1.14(0.24 ; 18.90)^{*}$ & $1.83 \pm 0.12$ & $23(13 ;>40)$ \\
\hline
\end{tabular}

*Difference not significant, Wilcoxon's rank sum test. 


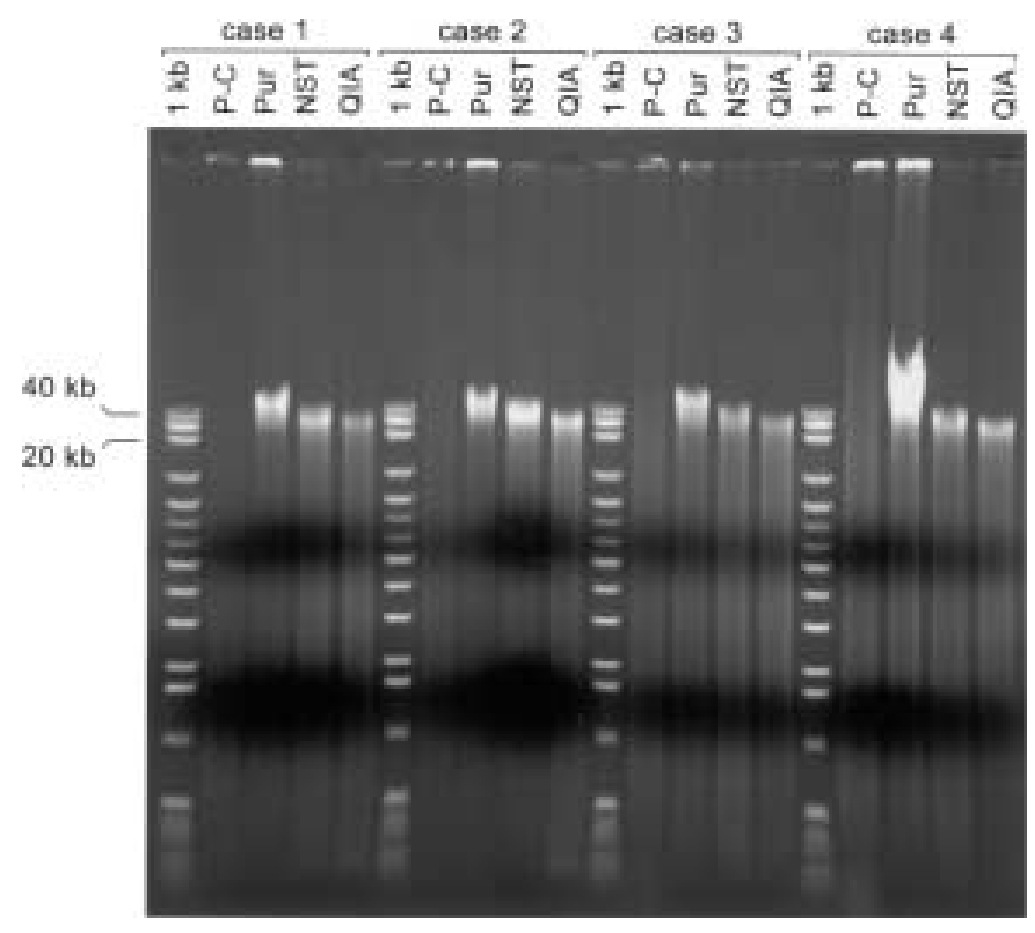

Fig. 1. DNA extracted from split samples of four bronchial aspirates (cases 1-4) and resolved by electrophoresis on $0.3 \%$ agarose gels. Of each case DNA was extracted with four different protocols: phenol-chloroform (P-C), Puregene (Pur), NucleoSpin Tissue (NST), and QIAamp DNA Mini Kit (QIA). 1 kb DNA Extension Ladder.

documented in Fig. 1 exemplary for four different cases investigated. It was not possible to resolve the DNA extracted with phenol-chloroform on a $0.3 \%$ agarose gel. Thus, conventional agarose gel electrophoresis utilized in this study was not able to detect any fragmentation of genomic DNA attributable to the fixative.

\subsection{DNA yields}

DNA yield was significantly dependent on the extraction method used (Table 1). Phenol-chloroform (P-C) produced the best DNA yield followed by the extraction kits Puregene (Pur), NucleoSpin Tissue (NST) and QIAamp DNA Mini Kit (QIA) $(p<$ 0.0001, P-C versus NST, Pur, and QIA; $p<0.0001$, Pur versus NST and QIA; $p=$ n.s., NST versus QIA). Irrespective of the DNA extraction method, the DNA yield of bronchial secretions varied considerably. No significant correlation was found between degree of inflammation and total DNA yield (data not shown).

\subsection{DNA purity}

DNA purity estimated as ratio of $A_{260} / A_{280}$ was sufficient irrespective of DNA extraction method used
(Table 1). The best purity was achieved with QIAamp DNA Mini Kit $(p<0.005)$ followed by Puregene, NucleoSpin Tissue and phenol-chloroform $(p<0.0001$, QIA versus NST and $\mathrm{P}-\mathrm{C} ; p<0.005$, QIA versus $\mathrm{Pur}$; $p<0.01$, Pur versus $\mathrm{P}-\mathrm{C} ; p<0.05$, Pur versus NST).

\subsection{DNA fragment size}

The DNA fragment size was clearly dependent on the extraction method used (Table 1). The differences between extraction protocols in fragment size were statistically highly significant $(p<0.0001)$. Without exception DNA extracted by phenol-chloroform had such high molecular weight that it did not migrate into the $0.3 \%$ agarose gel (Fig. 1). DNA of high molecular weight with a median fragment size above $40 \mathrm{~kb}$ was also extracted using Puregene. In addition, smaller fragments were detected (minimal fragment size $17 \mathrm{~kb}$ ). DNA isolated using the silica membrane based extraction kits NucleoSpin Tissue and QIAamp DNA Mini Kit was significantly more fragmentised producing a median fragment length of 26 and $23 \mathrm{~kb}$, respectively. The minimal fragment size was $13 \mathrm{~kb}$. 


\subsection{PCR amplification of $\beta$-globin gene fragments}

The extracts of each of the four split samples of 15 bronchial aspirates were successfully amplified for the three different sized $\beta$-globin gene fragments resulting in a total of 180 successful consecutive PCR amplifications. Since no differences were observed between the four DNA isolation methods until then, the PCR-series was stopped.

\section{Discussion}

Numerous previous studies used tissue specimens to investigate the influence of different fixatives and DNA extraction methods on the quality of genomic DNA [2, 3]. On the other hand, there are only few such studies that applied routine diagnostic cytologic specimens $[1,5,9]$. In this study we tested four different protocols of DNA extraction from bronchial secretions and evaluated the extracted DNA with regard to yield, purity, integrity, and adequacy for PCR-based assays. All bronchial aspirates had been fixed with Saccomanno fixative immediately after bronchoscopy as it excellently preserves cell morphology and effectively reduces bacterial growth [4,7]. We showed that this fixative also preserves sample DNA as high molecular weight DNA. There was no fragmentation of genomic DNA attributable to the fixative when investigated using conventional agarose gels.

Garcia-Closas and co-workers [1] evaluated mouthwash samples fixed by $14.3 \mathrm{wt} \%$ alcohol and also found high molecular weight DNA $(>23 \mathrm{~kb})$ in all cases. Another study analysed DNA samples fixed in $14.3 \mathrm{wt} \%$ alcohol by pulse-field gel electrophoresis [9]. The majority of the recovered DNA was between 35 and $63 \mathrm{~kb}$ (range, $>15-97 \mathrm{~kb}$ ). The occurrence of DNA fragments below $40 \mathrm{~kb}$ in both studies may be linked to some DNA damage resulting from the use of a fixative with only $14.3 \mathrm{wt} \%$ alcohol instead of $50 \%$ ethanol used in this study.

All four isolation methods tested extracted a DNA well suitable to amplify even large PCR-products. This was demonstrated by the amplification of three different sized $\beta$-globin gene fragments $(268,536$, and $989 \mathrm{bp})$. Kerstens et al. [5] used the same fixative (50\% ethanol/2\% carbowax) as we did for the fixation of cervix brushes and found it sufficient for reliable HPV screening with LiPA-PCR. Out of several fixatives tested by Greer et al. [2,3] 95\% ethanol belonged to those most successful in subsequent PCR amplifications producing DNA amplification fragments of up to $1327 \mathrm{bp}$ in length. However, alcohol of high concentration, as was used for tissue fixation in previous studies, coagulates mucoproteins and causes shrinkage of cells [7]. It is therefore not suitable for cytologic specimens. The usage of $14.3 \mathrm{wt} \%$ alcohol for the fixation of cytologic specimens proved a PCR success rate almost as high as found in this study and was only slightly less efficient with large (989 bp) PCR products ( $94 \%$ versus $100 \%$ ) [1]. However, the low alcohol content suppressed bacterial growth incompletely resulting in considerable contribution of bacterial DNA to total DNA content [1]. In this study none of the specimens showed relevant bacterial growth as evaluated by light microscopy.

In contrast to several other fixatives like formalin, alcohol fixation over a period of several days, e.g., during mailing, does not decrease the PCR success rate $[2,3]$.

Irrespective of DNA extraction method applied, the DNA yield of bronchial secretions varied considerably. This variation was not correlated to the degree of inflammation seen by light microscopic evaluation. It should be taken into consideration when planning a study using bronchial aspirates, that a considerable subset of the specimens may not be sufficient due to a low amount of total DNA.

This study showed that DNA yield, purity, and fragment size were significantly dependent on the DNA extraction protocol used. Phenol-chloroform extraction achieved the highest DNA yield and extracted the largest DNA fragments. DNA purity was slightly lower than that in other extraction methods, but still acceptable. Phenol-chloroform extraction has the advantage that the components can be adjusted to the considerably varying amounts of genomic DNA present in bronchial aspirates. However, the procedure is relatively time consuming and applies toxic chemicals. Remaining phenol does interfere with UVspectrophotometry. Thus it is necessary to additionally check the absorption at $230 \mathrm{~nm}$. The Puregene DNA extraction kit purifies the DNA by precipitating the proteins of the cellular lysate using ammonium acetate. Subsequently the DNA is precipitated with isopropanol. This method produced the second best results with regard to DNA yield, purity and fragment size which, in half of the cases, lies above $40 \mathrm{~kb}$. On the one hand, this protocol is as flexible as phenol-chloroform extraction concerning variable DNA amounts present, on the other hand, a relatively 
time consuming procedure. But it is not toxic. $\mathrm{Nu}-$ cleoSpin Tissue and QIAamp DNA Mini Kit work on the same principle. The DNA is bond onto silica membranes, is purified and then eluted. The protocols are quick and easy to perform even for inexperienced laboratory staff. In addition, no toxic chemicals have to be handled. But both methods produced a lower DNA yield than phenol-chloroform extraction and Puregene. In addition, the DNA was significantly more fragmentised. This is supported by experiments of other authors who also found that DNA prepared by binding to silica-based matrices tend to be of smaller size than DNA extracted with phenol-chloroform or the Puregene kit $[1,9]$. In this study the smallest DNA fragment extracted sized $13 \mathrm{~kb}$ and the median DNA fragment length was 26 (NucleoSpin Tissue) and 23 $\mathrm{kb}$ (QIAamp Kit) respectively. DNA extracts isolated by NucleoSpin Tissue came up with a slightly higher DNA fragment size, whereas DNA extracted by the QIAamp DNA Mini Kit showed the highest DNA purity of all protocols tested. As a consequence, both extraction kits are well suited if sufficient genomic DNA is present and a quick and easy DNA extraction method is desired.

In conclusion, fixation of bronchial aspirates by Saccomanno fixative provides genomic DNA well preserved for PCR-based methods in molecular cytology. Since the DNA content of bronchial aspirates varies considerably, extraction methods that can be adjusted to this appear favourable. However, the method of preference depends on the circumstances of application.

\section{Appendix. DNA extraction protocols}

\section{Phenol-chloroform DNA extraction [8]}

Place $200 \mu 1$ resuspended cells, $200 \mu 1$ lysate buffer (10 mM Tris-HCl pH 8.0, 0.1 M EDTA pH 8.0, 0.5\% SDS (w/v)) and $20 \mu \mathrm{l}$ proteinases $\mathrm{K}(20 \mathrm{mg} / \mathrm{ml})$ into a $1.5 \mathrm{ml}$ reaction tube and incubate at $65^{\circ} \mathrm{C}$ for $30 \mathrm{~min}$. Add $20 \mu \mathrm{g} / \mathrm{ml}$ DNase-free pancreatic RNase and incubate for $30 \mathrm{~min}$ at $37^{\circ} \mathrm{C}$. Add an equal volume of phenol-chloroform $(1: 1)$ and vortex for $10 \mathrm{~s}$. Centrifuge the probe at $15,000 \times g$ for $2 \mathrm{~min}$. Transfer the aqueous layer to a new tube, add an equal volume of chloroform and vortex for $10 \mathrm{~s}$. Centrifuge the probe at $15,000 \times g$ for $2 \mathrm{~min}$. Transfer the aqueous layer to a new tube. Add $0.1 \times$ volume of $3 \mathrm{M} \mathrm{NaOAc}(\mathrm{pH} 5.2)$ and $2 \times$ volume of $100 \% \mathrm{EtOH}$, vortex the probe and store it overnight at $-20^{\circ} \mathrm{C}$. Centrifuge the probe at $15,000 \times g$ for $10 \mathrm{~min}$. Wash the DNA pellet with $70 \%$ EtOH. Dry and resuspend the DNA in $50 \mu 110 \mathrm{mM}$ Tris- $\mathrm{HCl} \mathrm{pH} 8.0$.

\section{QIAamp DNA Mini Kit (according to manufacturer's instructions)}

Place $200 \mu \mathrm{l}$ resuspended cells, $20 \mu \mathrm{l}$ RNase A $(10 \mathrm{mg} / \mathrm{ml}), 20 \mu \mathrm{l}$ proteinases $\mathrm{K}(20 \mathrm{mg} / \mathrm{ml})$ and $200 \mu \mathrm{l}$ buffer AL in a $1.5 \mathrm{ml}$ reaction tube, vortex for $5 \mathrm{~s}$ and incubate at $56^{\circ} \mathrm{C}$ for $10 \mathrm{~min}$. Add $200 \mu \mathrm{l} 100 \% \mathrm{EtOH}$. Vortex the mixture for $5 \mathrm{~s}$ and apply it into the QIAamp spin column in a $2 \mathrm{ml}$ collection tube. Centrifuge the collection tube at $6000 \times g$ for $1 \mathrm{~min}$ and add $500 \mu \mathrm{l}$ buffer AW1. Centrifuge the spin column in a new collection tube at maximum speed for $1 \mathrm{~min}$. Add $500 \mu \mathrm{l}$ buffer AW2 and change the collection tube. Centrifuge at maximum speed for $1 \mathrm{~min}$, discard the flow-trough and centrifuge once more. Put the spin column onto a clean $1.5 \mathrm{ml}$ reaction tube, add $50 \mu \mathrm{l}$ buffer $\mathrm{AE}$ and incubate for $5 \mathrm{~min}$ at room temperature. Eluate the DNA by centrifugation at $6000 \times g$ for $1 \mathrm{~min}$.

\section{NucleoSpin Tissue (according to manufacturer's instructions)}

Place $200 \mu \mathrm{l}$ resuspended cells, $25 \mu \mathrm{l}$ proteinases $\mathrm{K}(20 \mathrm{mg} / \mathrm{ml})$ and $200 \mu \mathrm{l}$ buffer B3 in a $1.5 \mathrm{ml}$ reaction tube, vortex for $15 \mathrm{~s}$ and incubate at $70^{\circ} \mathrm{C}$ for 10 $30 \mathrm{~min}$. Digest RNA with $20 \mu \mathrm{l}$ RNase A (10 mg/ml) for $30 \mathrm{~min}$ at $37^{\circ} \mathrm{C}$. Add $210 \mu \mathrm{l} 100 \% \mathrm{EtOH}$. Vortex the mixture for $5 \mathrm{~s}$ and apply it onto the NucleoSpin column in a $2 \mathrm{ml}$ collection tube. Centrifuge the collection tube at $6000 \times g$ for $1 \mathrm{~min}$. Add $500 \mu \mathrm{l}$ buffer BW and centrifuge the spin column in a new collection tube at maximum speed for $1 \mathrm{~min}$. Add $600 \mu \mathrm{l}$ buffer B5 and change the collection tube. Centrifuge at maximum speed for $1 \mathrm{~min}$, discard the flow-trough and centrifuge once more. Place the spin column onto a clean $1.5 \mathrm{ml}$ reaction tube, add $50 \mu \mathrm{l}$ prewarmed $\left(70^{\circ} \mathrm{C}\right)$ buffer $\mathrm{BE}$ and incubate for $5 \mathrm{~min}$ at room temperature. Eluate the DNA by centrifugation at $6000 \times g$ for $1 \mathrm{~min}$.

\subsection{Puregene (according to manufacturer's instructions)}

Place $200 \mu \mathrm{l}$ resuspended cells in a $1.5 \mathrm{ml}$ reaction tube and centrifuge for $5 \mathrm{~min}$ at $600 \times \mathrm{g}$. Discard the supernatant and resolve the cell pellet in $50 \mu \mathrm{l}$. Add $250 \mu \mathrm{l}$ cell-lysis-buffer and $25 \mu \mathrm{l}$ of proteinases $\mathrm{K}(20 \mathrm{mg} / \mathrm{ml})$. Vortex for $15 \mathrm{~s}$ and incubate at $65^{\circ} \mathrm{C}$ for $30 \mathrm{~min}$. Digest RNA with $30 \mu \mathrm{l}$ RNase A-solution (4 mg/ml) for $15 \mathrm{~min}$ at $37^{\circ} \mathrm{C}$. Add $100 \mu \mathrm{l}$ proteinprecipitation-solution, vortex for $20 \mathrm{~s}$ and incubate for $5 \mathrm{~min}$ at $5^{\circ} \mathrm{C}$. Centrifuge at $13,000 \times g$ for $3 \mathrm{~min}$. The 
precipitated proteins should form a tight pellet, if not repeat this step. Transfer the supernatant in a $1.5 \mathrm{ml}$ reaction tube and add $300 \mu \mathrm{l}$ isopropanol. Mix by inverting the tube gently 50 times and incubate for $5 \mathrm{~min}$ at room temperature. Centrifuge at $13,700 \times g$ for $5 \mathrm{~min}$. Discard the supernatant and wash the DNA pellet with $70 \%$ EtOH. Dry pellet and rehydrate DNA in $50 \mu \mathrm{l}$ DNA-hydration-solution.

\section{References}

[1] M. Garcia-Closas, K.M. Egan, J. Abruzzo, P.A. Newcomb, L. Titus-Ernstoff, T. Franklin, P.K. Bender, J.C. Beck, L. Le Marchand, A. Lum, M. Alavanja, R.B. Hayes, J. Rutter, K. Buetow, L.A. Brinton and N. Rothman, Collection of genomic DNA from adults in epidemiological studies by buccal cytobrush and mouthwash, Cancer Epidemiol. Biomarkers Prev. 10 (2001), 687-696.

[2] C.E. Greer, J.K. Lund and M.M. Manos, PCR amplification from paraffin-embedded tissues: recommendations on fixatives for long-term storage and prospective studies, PCR Methods Appl. 1 (1991), 46-50
[3] C.E. Greer, C.M. Wheeler and M.M. Manos, Sample preparation and PCR amplification from paraffin-embedded tissues, PCR Methods Applications 3 (1994), S113-S122.

[4] Guidelines of the Papanicolaou Society of Cytopathology for the examination of cytologc specimens obtained from the respiratory tract. Papanicolaou Society of Cytopathology Task Force on Standards of Practice, Diagn. Cytopathol. 21 (1999), 61-69.

[5] H.M. Kerstens, J.C. Robben, P.J. Poddighe, W.J. Melchers, H. Boonstra, P.C. de Wilde, M.V. Macville and A.G. Hanselaar, AgarCyto: a novel cell-processing method for multiple molecular diagnostic analyses of the uterine cervix, J. Histochem. Cytochem. 48 (2000), 709-718.

[6] H. Motherby, S. Nicklaus, A. Berg, S. Ohler, B. Ross, M. Sarbia and A. Böcking, Semiautomated monolayer preparation of bronchial secretions using AutoCyte PREP, Acta Cytol. 43 (1999), 47-57.

[7] G. Saccomanno, The contribution of uranium miners to lung cancer histogenesis, Rec. Results Cancer Res. 82 (1982), 4352 .

[8] J. Sambrook and D.W. Russell, Molecular Cloning: A Laboratory Manual, Cold Spring Harbor Laboratory Press, Cold Spring Harbor, NY, 2001.

[9] K. Tobal, D.M. Layton and G.J. Mufti, Non-invasive isolation of constitutional DNA for genetic analysis, Lancet $\mathbf{8 6 7 4}$ (1989), 1281-1282. 


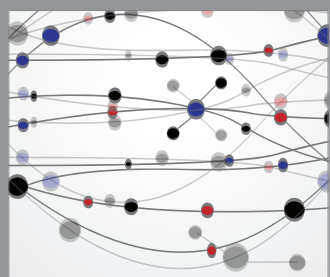

The Scientific World Journal
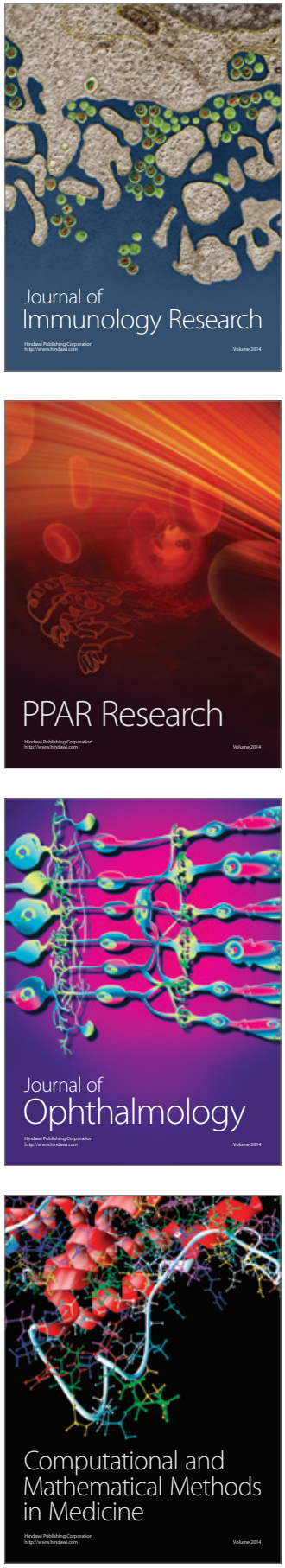

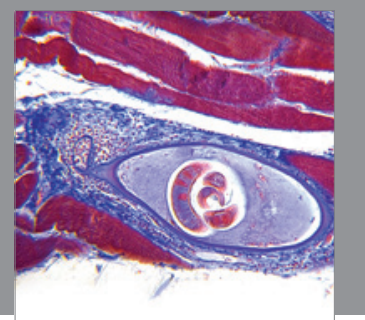

Gastroenterology

Research and Practice
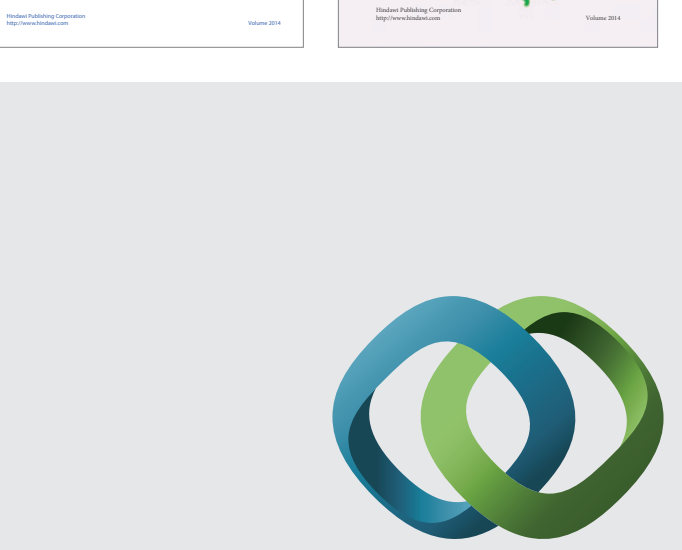

\section{Hindawi}

Submit your manuscripts at

http://www.hindawi.com
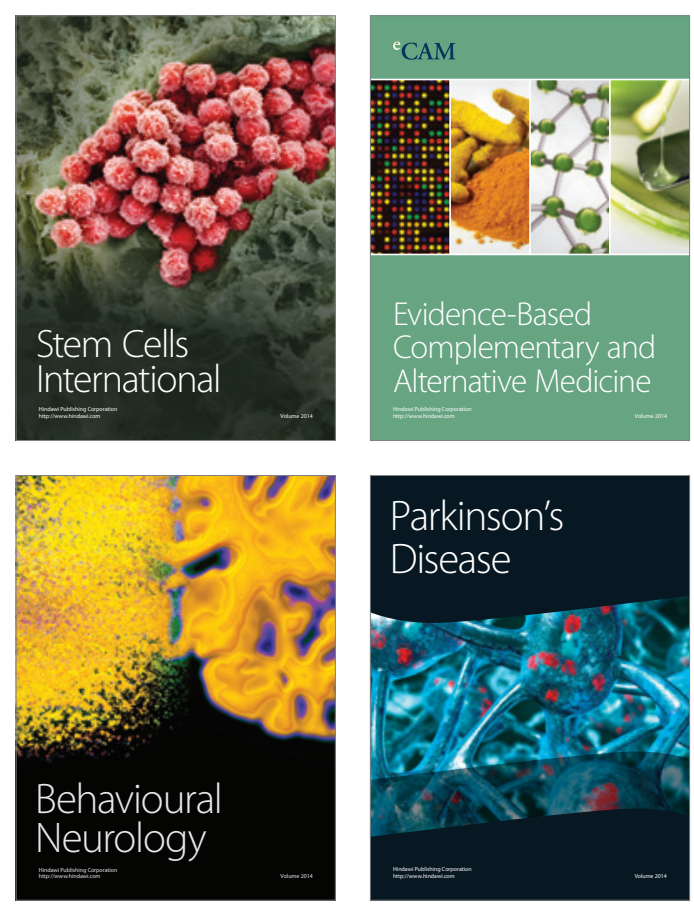

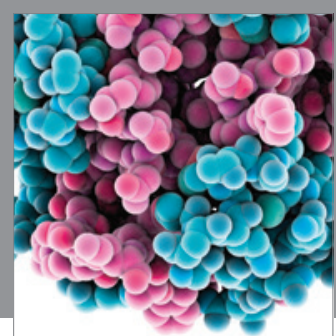

Journal of
Diabetes Research

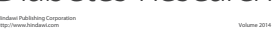

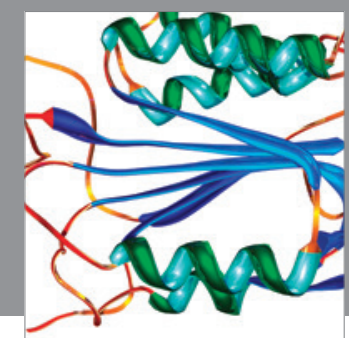

Disease Markers
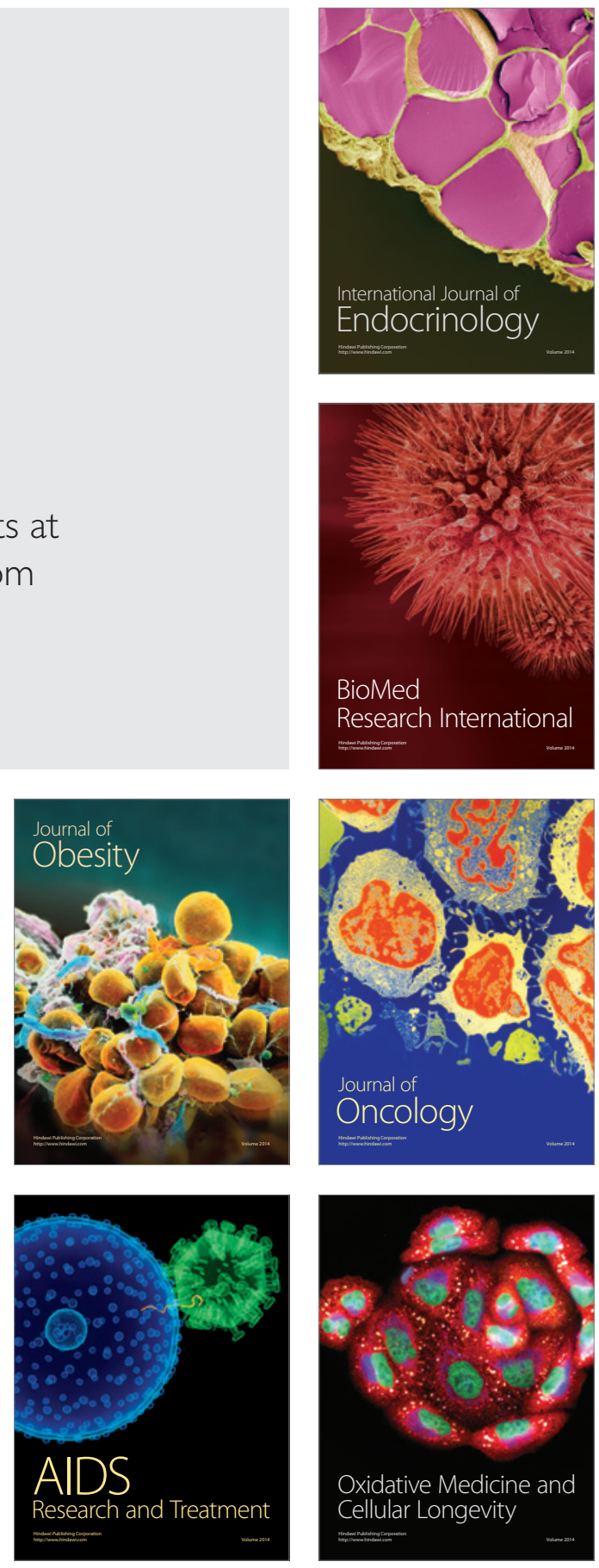